\title{
A combfejcsavar helyzetének prognosztikai jelentősége a csípőtáji törések esetén
}

\author{
Csonka Ákos dr. - Ecseri Tamás dr. - Dózsai Dávid dr. \\ Csonka István dr. - Gárgyán István dr. - Varga Endre dr.
}

Szegedi Tudományegyetem, Általános Orvostudományi Kar, Traumatológiai Klinika, Szeged

\begin{abstract}
Bevezetés: Tanulmányunkban a magyar lakosság egyik leggyakoribb sérülésével, a csípótáji törésekkel, azon belül a pertrochanter és a lateralis combnyaktörésekkel foglalkoztunk. A svájci Osteosynthesis Munkaközösség (AO) klasszifikációja szerinti 31-Al-es és 31-A2-es töréseket vizsgáltuk, melyek gyakorisága a kor elörehaladtával egyre inkább növekszik.

Módszer: A 2010 és 2016 közötti időszakban kezelt 1179 beteg adatait elemeztük. A töréseket intramedullaris szegek alkalmazásával stabilizáltuk. 992 betegnél Stryker Gamma3 ${ }^{\circledR}$, míg 187 betegnél Synthes PFNA ${ }^{\circledR}$ szeget alkalmaztunk. Extenziós asztalon, a töréseket képerősítő segítségével, fedetten reponáltuk. A mútéteket általános anesztéziában vagy epiduralis érzéstelenítésben traumatológus szakorvosok vagy rezidensek végezték standard lateralis feltárásból. Az adatokat és méréseket a klinikán használt, úgynevezett GEPACS-alkalmazásból nyertük. Ezt követően statisztikai elemzéseket végeztünk a Microsoft Excel táblázatszerkesztő program segítségével.

Eredmények: Cut-out a vizsgált betegek közül 33 (2,79\%) esetben következett be. Ebből 21 (1,78\%) esetben a bal, míg 12 (1,01\%) esetben a jobb oldalon. 29 (87,87\%) esetben Gamma3 szeget, 4 (12,12\%) esetben PFNA szeget használtunk. Szövődményes eseteinkben a tip-apex distance (TAD-) index átlaga $18 \mathrm{~mm}$ volt.

Következtetés: A dynamic hip screw (DHS) alkalmazása esetén a TAD-indexnek az irodalmi ajánlások szerint $20 \mathrm{~mm}$ nek vagy annál kisebbnek kell lennie. A TAD-index átlagértéke a cut-out csoportban $18 \mathrm{~mm}$ volt, ami megegyezik a szövődménymentes csoport átlagos TAD-index-értékével. Eredményeinkből az derült ki, hogy a fejcsavar kivágásának bekövetkezte független a TAD-indextől, így ez az ajánlás nem alkalmazható megbízhatóan a velőűrszegek esetében.

Orv Hetil. 2019; 160(9): 338-342.
\end{abstract}

Kulcsszavak: cut-out, TAD-index, intertrochantericus femurtörés, Gamma3, protimalis csípótáji szeg

\section{The prognostic value of the hip screw position in intertrochanteric fractures}

Introduction: In our study, we analyzed one of the Hungarian population's most frequent injuries, the hip fracture, focusing mainly on the lateral femoral neck and the pertrochanteric fractures. According to the classification of the Swiss Association for Ostheosynthesis (AO), we focused on 31-Al and 31-A2 fractures, the incidence of which increases by ageing.

Method: Between 2010 and 2016, we analyzed the data of 1179 patients. All of the fractures were stabilized with intramedullary nails. 992 patients received Stryker Gamma $3^{\circledR}$, whereas 187 patients’ fractures were solved with Synthes PFNA ${ }^{\circledR}$ nail. In all cases, closed reduction method was used with fluoroscopy on an extension table. The surgeries were done in general or epidural anesthesia and performed by traumatology residents or specialists using standard lateral exploration. Data were collected using GEPACS software and statistical analysis was done with MS Excel.

Results: Cut-out occurred in 33 cases $(2,79 \%)$ : out of that $21(1.78 \%)$ were left sided and 12 were $(1,01 \%)$ right sided. $29(87.87 \%)$ patients were treated with Gamma3 nail, and in $4(12,12 \%)$ cases PFNA nail was used. The average TAD-index was $18 \mathrm{~mm}$.

Conclusion: According to recommendations of the TAD-index value, when using dynamic hip screw, it should be 20 $\mathrm{mm}$ or lower. The average index value was $18 \mathrm{~mm}$ which was equal in the complicated and non-complicated groups. Our study shows that the cut-out is independent from the TAD-index value, thus this recommendation cannot be applied for intramedullary nails. 
Keywords: cut-out, tip-apex distance, intertrochanteric fracture of the femur, the third generation Gamma nail, proximal femoral nail anti-rotation

Csonka Á, Ecseri T, Dózsai D, Csonka I, Gárgyán I, Varga E. [The prognostic value of the hip screw position in intertrochanteric fractures]. Orv Hetil. 2019; 160(9): 338-342.

(Beérkezett: 2018. október 15.; elfogadva: 2018. november 25.)

\begin{abstract}
Rövidítések
31-Al = egyszerü pertrochanter törés; $31-\mathrm{A} 2=$ darabos pertrochanter törés; $\mathrm{AO}=($ Arbeitsgemeinschaft für Osteosynthesefragen) Ostheosynthesis Munkaközösség; AP = anteroposterior; $\mathrm{CI}=($ confidence interval $)$ konfidenciaintervallum; $\mathrm{DHS}=$ (dynamic hip screw) dinamikus csípőcsavar; PFNA = (proximal femoral nail anti-rotation) proximalis csípőtáji szeg; $\mathrm{RR}=$ (risk ratio) kockázati arány; TAD = (tip-apex distance $)$ combfejcsavar helyzete; $\mathrm{WHO}=$ (World Health Organization) Egészségügyi Világszervezet
\end{abstract}

A csípőtáji törések a leggyakrabban a 70 év feletti betegpopulációt érintik. Ebben az életkorban számos egyéb betegség, illetve rizikófaktor is fennáll, ezért ellátásuk nagy kihívást jelent a baleseti sebészek számára. A menynyiségi kritériumok mellett a csont minősége és szerkezete is befolyást gyakorol a csontok teherviselő képességére. A kockázati tényezők vizsgálatának indokoltságát az is alátámasztotta, hogy az úgynevezett kis traumás törést elszenvedők csaknem felénél a T-score-érték nem éri el a WHO által megadott határértéket, bár maga a törés egyértelműen a csontanyagcsere-betegség következménye [1]. A családi anamnézisben szereplő korábbi osteoporoticus csonttörés a betegek csonttörési valószínûségét körülbelül 20\%-kal növeli meg (RR: 1,18; 95\% CI: 1,06-1,31), míg a csípőtáji törés veszélyét a másfélszeresére fokozza (RR: 1,49; 95\% CI: 1,17-1,89) [2]. A csípőtáji törések jelentős gondot jelentenek a társadalom számára, mivel mortalitásuk magas, az életminőséget nagymértékben rontják, ezenkívül ellátásuk igen költséges [3]. Fontos prognosztikai tényező az osteoporosis, amely világszerte több száz millió embert sújt. Hazánkban körülbelül 900000 ember érintett. A betegség kezelésében és a törések megelőzésében az elmúlt években elsődlegesen a biszfoszfonáttartalmú készítményeket részesítették előnyben [4]. Emellett a törések bekövetkeztében szerepet játszanak a különböző egyensúlyzavarok miatti esések, az exsiccosis, illetve az alkoholabúzus stb. A törések ellátásában a sebészi megoldás az „arany standard", hacsak a betegnek nincs olyan komorbiditása, amely a mútétet kontraindikálná. Világszerte évente több mint 700000 ember halálát okozzák a csípőtáji törések és azok szövődményei, ezért rendkívül fontos a megfelelő műtéti technika alkalmazása és a posztoperatív kezelés. Az intramedullaris szegek alkalmazása a pertrochanter törések kezelésében az utóbbi két évtizedben vált rendszeresen alkalmazott módszerré. Az intrame- dullaris szegek esetén, a combfej és a szeg között kisebb az erőkar, ezért kisebb a forgatónyomaték is, összehasonlítva a DHS-rendszerrel. Ez lehetővé teszi a terhelés megoszlását és a stabilitás fokozását. Habár az intramedullaris szegek biomechanikai előnyei jobb klinikai kimenetelt eredményeznek, ennek ellenére számos szövődmény kialakulásának rizikója megnő, ilyen például a metaphysealis femur törése vagy a fejcsavarkivágás [5]. Mind a Gamma3 (Stryker Corporation, Kalamazoo, MI, Egyesült Államok), mind a PFNA (J\&J DePuy Synthes, USA) a velőúrszegek csoportjába tartozik, melyek által terhelésstabil osteosynthesis nyerhető. Az intramedullaris szegek előnyei között kiemelendő, hogy minimális mértékben károsítják a környező lágyrészeket. A beültetett implantátumok nagyobb teherbírásúak, mint a környező csont, ezért jobban ellenállnak a testsúly okozta multidirekcionális terhelésnek [6].

Mint minden orvosi beavatkozás alkalmával, a csípőtáji törések kezelésekor is kialakulhatnak szövődmények. Intramedullaris szegek alkalmazása esetén gyakori szövődmény az úgynevezett cut-out. Ez a fejcsavar combfejben történő medialis vagy cranialis irányú elmozdulása (1. ábra).

A pertrochanter töréseknél használt szögstabil dinamikus combfejcsavar alkalmazásakor jelentkező sikertelen törésrögzítés gyakran összefügg a fejcsavar pozíciójával a combfejben. Baumgaertner és mtsai 1995-ben közzétett cikkükben egységes mérési képletet alkottak a fejcsavar helyzetére vonatkozóan a combfejben. Ez definíció szerint a „tip-apex distance”, vagy „TAD-index”, amely a fejcsavar csúcsától a combfej csúcsáig mért távolság számtani összege anterior és lateralis röntgenfelvételen (2. ábra). Ebből az értékből következtetni lehet, hogy milyen érték mellett fordulhat elő a fejcsavar kivágása [7].

Az irodalmi adatok alapján, ha a TAD-index $25 \mathrm{~mm}$ nél nagyobb, a fejcsavar kivágásának lehetősége fokozódik. Törekedni kell arra, hogy a csípőtáji törések stabilizációja során a TAD-index $25 \mathrm{~mm}$ vagy annál kisebb legyen. PFNA esetén $10 \mathrm{~mm}$-es távolságnak kell lennie a fejcsavar medialis vége és a subchondralis csontállomány között mind AP, mind lateralis röntgenfelvételen. PFNA alkalmazása során az irodalom által említett fejcsavarkivágási gyakoriság megközelíti a $8 \%$-ot [8]. Nem fordultak elő szövődmények, amikor a TAD-index 20-30 mm volt [9]. Az optimális TAD-index DHS alkalmazása esetén $\leq 25 \mathrm{~mm}$ [10]. A fejcsavar cut-out visszavezethető a 


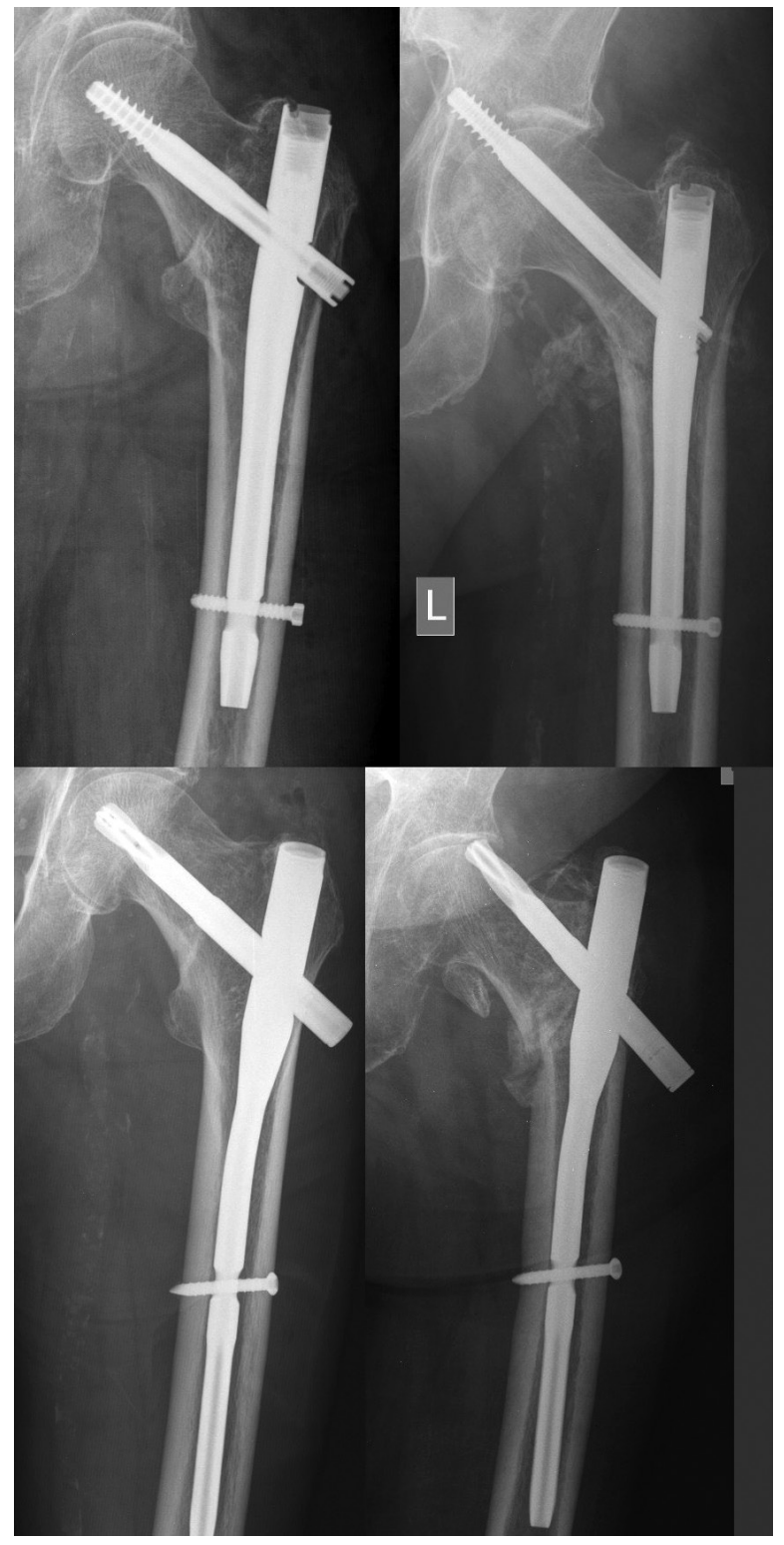

1. ábra

Gamma3 fejcsavar és PFNA fejpenge posztoperatív és cut-out röntgenfelvételei

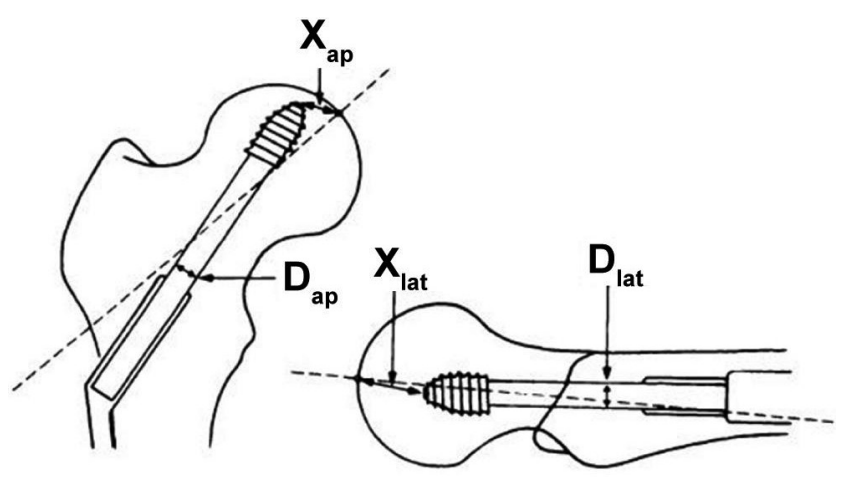

$T A D=\left(X_{\text {ap }} \times \frac{D_{\text {true }}}{D_{\text {ap }}}\right)+\left(X_{\text {lat }} \times \frac{D_{\text {true }}}{D_{\text {lat }}}\right)$

2. ábra A TAD-index kiszámításának képlete mútét során elkövetett technikai hibákra, valamint a csont minőségi jellemzőire. Előfordul, hogy a fejcsavar mediális irányba vándorol, és annak combfejen keresztüli migrációját okozza [11]. Az osteoporoticus csontállomány növeli az implantátum kivágási valószínúségét [12].

\section{Célkitüzés}

Vizsgálataink során a TAD-index klinikai jelentőségét elemeztük lateralis combnyak- és pertrochanter törések intramedullaris szegekkel történt rögzítése során. Áttekintettük a szakirodalmi ajánlásokat, valamint elemeztük a klinikánkon észlelt és kezelt betegek adatait. Vizsgáltuk, hogy a DHS-rendszer esetén javasolt TAD-index alkalmazható-e velőurrszegek esetén a fejcsavar-migráció prognózisának megítélésére.

\section{Módszer}

A 2010 és 2016 közötti időszakban a klinikánkon kezelt 1179 beteg adatait elemeztük, ebből 837 nő $(70,99 \%)$ és 342 férfi $(29,01 \%)$ volt. A sérülteket Gamma3, illetve PFNA velőürszegekkel kezeltük. A betegeket demográfiai jellemzőik, a törések oldalisága és az AO-beosztás alapján csoportosítottuk. A pertrochanter és a lateralis combnyaktörések esetén vizsgáltuk a TAD-index és az intramedullaris szegek fejcsavarjainak cut-out közti korrelációját. Az adatokat a GEPACS-alkalmazásból nyertük. Ezt követôen statisztikai elemzéseket végeztünk az Excel táblázatkészítő program (Microsoft Corporation, Redmond, WA, Egyesült Államok) segítségével. Kiszámoltuk a röntgenfelvételek alapján a posztoperatív TADindex-értékeket, valamint a törésgyógyulás során vizsgáltuk az implantátummigrációkat. A röntgenfelvételek kiértékelését minden esetben független személy végezte, aki nem vett részt a beteg ellátásában.

\section{Eredmények}

A vizsgálatban részt vevő betegek átlagéletkora 79,59 év volt. A nemek közti megoszlás tekintetében női dominanciát figyeltünk meg. A koreloszlást tekintve a vizsgált betegeink többsége 80 éves vagy annál idősebb. A sérülések oldaliságának megoszlását tekintve közel azonos számban fordultak elő jobb, illetve bal oldali törések.

Az AO-klasszifikáció szerint a következô eloszlás alakult ki (31-Al: 44,61\%, 31-A2: 55,39\%). A leggyakoribb TAD-index $17 \mathrm{~mm}$ volt (3. ábra). A szövődményeket tekintve az 1179 betegból 33 esetben észleltünk cut-out szövődményt. Ebből 24 esetben 31-A2-es, 9 esetben 31-Al-es törés volt. A 33 esetből 21 betegnek bal oldali, 12-nek jobb oldali törésében alakult ki szövődmény (4. ábra). 


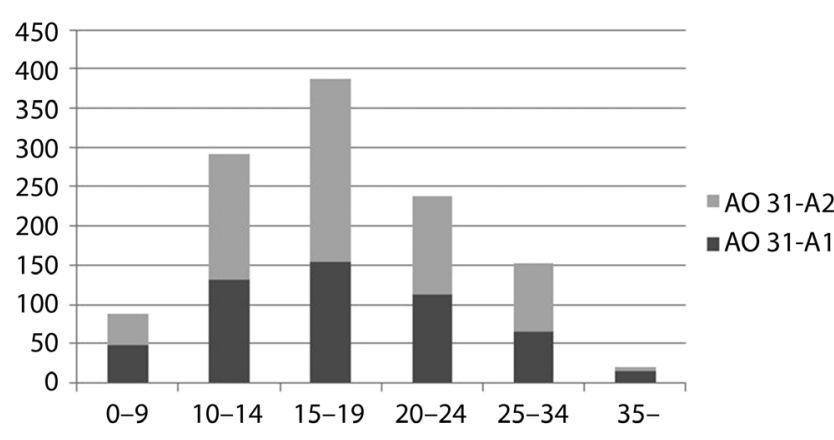

3. ábra $\quad$ A TAD-indexek megoszlása beteganyagunkban

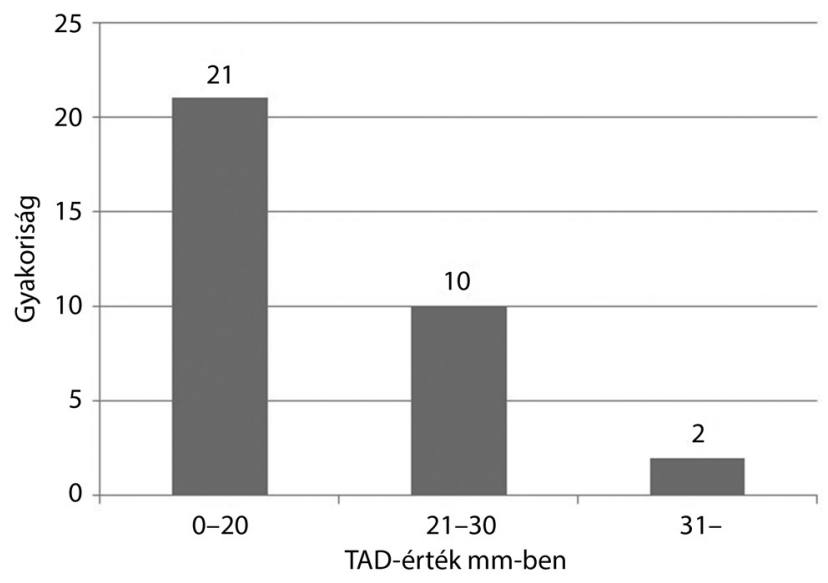

4. ábra | Szövődményes esetek és a TAD-index-értékek változása

\section{Megbeszélés}

A velőurrszegek 1,78-szor nagyobb tengelyirányú terhelést képesek elviselni instabil proximalis femurtörések esetében, mint a lateralis felszínre helyezett lemezek [13]. A törés repozícióját, a distalis reteszelés típusát és a fejcsavar helyzetét (TAD-index és Cleveland-zóna) intraoperatív és posztoperatív röntgenfelvételeken vizsgálva a szövődménymentes esetekben $86 \%$-ban centrális elhelyezkedésű volt a csavar. A fejcsavarral összefüggő szövődmények esetén a perifériás elhelyezkedés a betegek 55\%-ára volt igaz. Biomechanikai szempontból jelenleg a velőúrszegek jelentik a legjobb választást az instabil csípőtáji törések kezelésében. Az intramedullaris szeg használata során kisebb mértékủ forgatónyomaték keletkezik a kisebb erókar miatt $[6,14]$.

A PFNA szeg esetén a cut-out összefügg a fejpenge kialakításával, ami medialis perforációt okozhat a subchondralis csontállományban [15]. Kopperdabl és mtsai [16] vizsgálataik során 16,8 mm-es átlagos TAD-indexértéket írtak le. Fontos, hogy a fejpenge vége ne legyen 10 mm-nél közelebb a subchondralis csonthoz. A PFNA szeg esetén a fejpenge az alakjánál fogva kisebb felületen érintkezik a csonttal tengelyirányban. A kontaktfelszín $75 \mathrm{~mm}^{2}$-es, míg ugyanez a Gamma3 szeg esetében 300 $\mathrm{mm}^{2}$. PFNA alkalmazása esetén a TAD-index javasolt értéke 25-30 mm közötti [16].
A femur lateralis falának integritása kiemelten fontos az instabil törések rögzítése szempontjából. Az AO szerinti 31-A2-es törés esetén a fejcsavar beillesztési helye $1,5-2,5 \mathrm{~cm}$-rel a trochanter major lateralis izomtapadási pontja alatt van, ami fokozza a lateralis cortex károsodását, ezzel csökkentve a nagy tomporra eső rögzítés mértékét. A fejcsavar behelyezése szintén növelheti a lateralis fal károsodását, ez pedig rontja a korai törésgyógyulást. A proximalis tört darab felfúrása szintén a lateralis cortex károsodását idézheti elő. Gamma3 szeg behelyezése során, a veloúrfelfúrás következtében, a corticalis falvastagság csökkenése miatt iatrogén femur diaphysis törés jöhet létre. Osteoporoticus betegek esetében ez a szövődmény még gyakrabban fordul elő [17].

A femur antecurvációja miatt hosszabb szeg bevezetése hosszabb felfúrást igényelhet. Ez a combcsont metaphysealis cortexének vékonyításához vezet [18].

Gamma3 esetén a szeg proximalis vége közel helyezkedik el a fejcsavar furatához, és ez fokozza az implantátumra jutó stresszt, ezért alakulhat ki metaphysealis törés a szeg proximalis harmadában [19].

A megfelelő fejcsavar-pozicionálás mind $\mathrm{AP}$, mind lateralis irányból alapvető fontosságú. Abban az esetben, ha a törést jelentős mértékben elmozdult helyzetben rögzítjük, szignifikánsan nő a cut-out veszélye. A combfej varus helyzetbe billenése miatt a fejcsavar a cranialison vág ki. Megfelelő sebészi technikával a szövődményes esetek többsége megelőzhető, az esetek kis százalékában azonban az elsődleges hiba nem teljesen nyilvánvaló. Az osteoporosis kulcsszerepet játszik az osteosynthesis stabilitása és a törés gyógyulása szempontjából [20].

\section{Következtetés}

Összehasonlítva adatainkat a nemzetközi szakirodalommal, eredményeink alapján nem igazolódott, hogy 25 mm-nél magasabb TAD-index esetén nagyobb valószínúséggel következik be cut-out (p-érték: 0,01). Szignifikánsan kimutatható, hogy a fejcsavar kivágásának bekövetkezte független a TAD-indextől, ezért ez az ajánlás nem alkalmazható megbízhatóan a velőurrszegek esetében. Szövődményeink többsége $20 \mathrm{~mm}$-es TAD-indexérték alatt jött létre (p-érték: 0,001). Cut-out esetén a TAD-index átlagértéke $18 \mathrm{~mm}$ volt, ami megegyezett a szövődménymentes csoportéval. Tanulmányunk alapján korlátozott jelentőségú a TAD-index mérése velőúrszegek esetén, mert nincs prognosztikai szempontból jelentősége a hosszú távú fejcsavarrögzítés megítélése szempontjából. Cut-out esetén a legkisebb TAD-index-érték $2 \mathrm{~mm}$ volt, míg a legnagyobb $39 \mathrm{~mm}$. Szövődménymentes esetben ez az érték szélesebb tartományban mozgott, $1 \mathrm{~mm}$ és $55 \mathrm{~mm}$ között változott. Betegeink többsége postmenopausalis korban lévő nő volt, ezért az osteoporosis feltehetôen nagyobb szerepet játszott az implantátumelégtelenségek bekövetkeztében és a fejcsavar kivágásában. Fontos, hogy betegeink mozgásfunkcióját 
egyszerü funkcionális tesztekkel ellenőrizzük, melyek alapján a csonttörés valószínúségét pontosabban jelezhetjük előre [1]. Több nemzetközi tanulmány elemezte a szekunder, vagy ellenoldali csípőtáji törések előfordulását, amelyek értéke 2,7\% és 9\% között változott az első évnél. Hazai adatok alapján a csípőtáji töréseket követő ellenoldali törések előfordulása egy év alatt 1,5\% és 2,1\% között változott, a kumulatív incidencia $8,24 \%$ volt [21]. A mútéti beavatkozások után végzendő laboratóriumi vizsgálatok során célszerű lenne a $25(\mathrm{OH}) \mathrm{D}$-vitamin- és kalciumszint meghatározása is. Az esetek többségében számolnunk kell egyéb társuló betegségek előfordulásával is. Ezek közül több befolyásolja a D-vitamin felszívódását és annak metabolizmusát (malabszorpciós szindrómák, máj-, veseelégtelenség és a malignus kórképek). Mindezek mellett a cardiovascularis rizikó is mérlegelendő a kalcium adása előtt [22].

Anyagi támogatás: A közlemény megírása, illetve a kapcsolódó kutatómunka anyagi támogatásban nem részesült.

Szerzői munkamegosztás: Cs. Á.: A kézirat megszövegezése, irodalmi áttekintés. E. T.: Adatgyújtés. D. D.: Statisztikai elemzés. Cs. I.: Ábraszerkesztés. G. I.: Szakmai tanácsadás, lektorálás. V. E.: Szupervízori munka. A cikk végleges változatát valamennyi szerző elolvasta és jóváhagyta.

Érdekeltségek: A szerzőknek nincsenek érdekeltségeik.

\section{Irodalom}

[1] Ferencz V, Horváth Cs, Huszár S, et al. Evaluation of risk factors for fractures in postmenopausal women with osteoporosis. [A csonttörés kockázati tényezőinek vizsgálata postmenopausás, osteoporosisos nóbetegek körében.] Orv. Hetil. 2015; 156: 146-153. [Hungarian]

[2] Kanis JA, Johansson H, Oden A, et al. A family history of fracture and fracture risk: a meta-analysis. Bone 2004; 35: 1029 1037.

[3] Somogyi P, Kricsfalusy M, Gaál J, et al. The significance of hip fractures in view of Hungarian data. [Csípőtáji törések jelentősége a magyarországi adatok tükrében.] Osteol Közl. 2010; 10: 6772. [Hungarian]

[4] Rejnmark L, Mosekilde L. New and emerging antiresorptive treatments in osteoporosis. Curr Drug Saf. 2011; 6: 75-88.

[5] Sadowski C, Lübbeke A, Saudan M, et al. Treatment of reverse oblique and transverse intertrochanteric fractures with use of an intramedullary nail or a $95^{\circ}$ screw-plate: a prospective, randomized study. J Bone Joint Surg Am. 2002; 84-A: 372-381.

[6] Al-yassari G, Langstaff RJ, Jones JW, et al. The AO/ASIF proximal femoral nail (PFN) for the treatment of unstable trochanteric femoral fracture. Injury 2002; 33: 395-399.
[7] Baumgaertner MR, Curtin SL, Lindskog DM, et al. The value of the tip-apex distance in predicting failure of fixation of peritrochanteric fractures of the hip. J Bone Joint Surg Am. 1995; 77: 1058-1064.

[8] Goffin JM, Pankaj P, Simpson AH, et al. Does bone compaction around the helical blade of a proximal femoral nail anti-rotation (PFNA) decrease the risk of cut-out? A subject-specific computational study. Bone Joint Res. 2013; 2: 79-83.

[9] Nikoloski AN, Osbrough AL, Yates PJ. Should the tip-apex distance (TAD) rule be modified for the proximal femoral nail antirotation (PFNA)? A retrospective study. J Orthop Surg Res. 2013; 8: 35 .

[10] Zirngibl B, Biber R, Bail HJ. How to prevent cut-out and cutthrough in biaxial proximal femoral nails: is there anything beyond lag screw positioning and tip-apex distance? Int Orthop. 2013; 37: 1363-1368.

[11] Curtis MJ, Jinnah RH, Wilson V, et al. Proximal femoral fractures: a biomechanical study to compare intramedullary and extramedullary fixation. Injury 1994; 25: 99-104.

[12] Yaacobi E, Sanchez D, Maniar H, et al. Surgical treatment of osteoporotic fractures: an update on the principles of management. Injury 2017; 48(Suppl 7): S34-S40.

[13] Bhandari M, Schemitsch E, Jönsson A, et al. Gamma nails revisited: gamma nails persus compression hip screws in the management of intertrochanteric fractures of the hip: a meta-analysis. J Orthop Trauma 2009; 23: 460-464.

[14] Halder SC. The Gamma nail for peritrochanteric fractures. J Bone Joint Surg Br. 1992; 74: 340-344.

[15] Zhou JQ, Chang SM. Failure of PFNA: helical blade perforation and tip-apex distance. Injury 2012; 43: 1227-1228.

[16] Kopperdahl DL, Keaveny TM. Yield strain behavior of trabecular bone. J Biomech. 1998; 31: 601-608.

[17] Gotfried Y. The lateral trochanteric wall: a key element in the reconstruction of unstable pertrochanteric hip fractures. Clin Orthop Relat Res. 2004; 425: 82-86.

[18] Ricci WM, Gallagher B, Haidukewych GJ. Intramedullary nailing of femoral shaft fractures: current concepts. J Am Acad Orthop Surg. 2009; 17: 296-305.

[19] Alvarez DB, Aparicio JP, Fernández EL, et al. Implant breakage, a rare complication with the Gamma nail. A review of 843 fractures of the proximal femur treated with a Gamma nail. Acta Orthop Belg. 2004; 70: 435-443.

[20] Weil YA, Gardner MJ, Mikhail G, et al. Medial migration of intramedullary hip fixation devices: a biomechanical analysis. Arch Orthop Trauma Surg. 2008; 128: 227-234.

[21] Juhász K, Boncz I, Kanizsai P, et al. Analysis of the prognostic factors influencing the time elapsing until the contralateral hip fracture. [Az ellenoldali csípőtáji törésig eltelt időt befolyásoló prognosztikai tényezók vizsgálata.] Orv Hetil. 2018; 159: 15431547. [Hungarian]

[22] Salamon A, Toldy E, Biró C, et al. Vitamin D and calcium supplementation in elderly patients considering the prevention of hip fractures. [D-vitamin- és kalciumpótlás az időskori csípőtáji törések megelőzésében.] Orv Hetil. 2017; 158: 1699-1707. [Hungarian]

(Csonka Ákos dr., Szeged, Semmelweis u. 6., 6725 e-mail: csonka.akos81@gmail.com)

A cikk a Creative Commons Attribution 4.0 International License (https://creativecommons.org/licenses/by/4.0/) feltételei szerint publikált Open Access közlemény, melynek szellemében a cikk bármilyen médiumban szabadon felhasználható, megosztható és újraközölhetö, feltéve, hogy az eredeti szerző és a közlés helye, illetve a CC License linkje és az esetlegesen végrehajtott módositások feltüntetésre kerülnek. (SID_1) 